\title{
Kebijakan Penanggulangan Gelandangan dan Pengemis (Studi Penelitian Di Kabupaten Aceh Utara)
}

\author{
Yusrizal $^{1}$ dan Romi Asmara ${ }^{2}$ \\ ${ }^{12}$ Dosen Fakultas Hukum Universitas Malikussaleh
}

\begin{abstract}
Abstrak
Penelitian ini adalah penelitian yuridis normatif yang mencoba melihat kebijakan-kebijakan yang diambil oleh pemerintah daerah kabupaten Aceh Utara tentang penanggulangan gelandangan dan pengemis. Studi penelitian ini menunjukkan ada beberapa kebijakan penanggulangan gelandangan dan pengemis yang telah dilakukan oleh Pemerintah Kabupaten Aceh Utara melalui Dinas Sosial, Pemberdayaan Perempuan dan Perlindungan Anak Kabupaten Aceh Utara serta Satuan Polisi Pamong Praja, diantaranya adalah: melakukan penertiban/razia terhadap gelandangan dan pengemis, upaya pemberdayaan Pengemis, seperti diberikan pelatihan keahlian sesuai minat dan bakat, juga adanya pemberdayaan ekonomi yang bersifat produktif yang anggarannya berasal dari anggaran pemerintah kabupaten maupun provinsi, diberikannya bantuan langsung tunai untuk menopang perekonomian yang termasuk penyandang masalah kesejahteraan sosial yang cacat secara fisik.
\end{abstract}

Kata Kunci: Kebijakan, Gelandangan, Pengemis 


\section{PENDAHULUAN}

Seiring dengan perkembangan zaman yang membawa bangsa Indonesia kearah globalisasi sedikit banyaknya telah membawa permasalahan tersendiri bagi bangsa Indonesia. Diantaranya adalah timbulnya permasalahan gelandangan dan pengemis.

Persoalan gelandangan dan pengemis merupakan isu nasional, didalam Undang-Undang Dasar 1945, Pasal 34 disebutkan bahwa fakir miskin dan anak-anak terlantar dipelihara oleh Negara. Hal ini ditegaskan juga dalam UndangUndang No. 40 Tahun 2004 Tentang Sistem Jaminan Sosial Nasional dan Undang-Undang No.11 Tahun 2009 Tentang Kesejahteraan Sosial. Undang-undang ini memberikan ruang bagi terbukanya pemenuhan kesejahteraan tak terkecuali gelandangan dan pengemis. Hal ini menyebabkan, perlunya upaya ekstra keras untuk mengindentifikasi dan meneliti keberadaan para gelandangan dan pengemis untuk memastikan tindakan yang tepat untuk mengatasinya.

Tidak ada satupun manusia terlahir dan hidup didunia ini berkeinginan menjadi gelandangan dan pengemis, melihat banyaknya gelandangan dan pengemis di Kabupaten Aceh Utara pasca konflik dan tsunami Aceh, maka peneliti berkeinginan untuk meneliti lebih lanjut mengenai upaya penaggulangan yang telah dilakukan oleh Pemerintah Kabupaten Aceh Utara dalam hal kebijakan yang telah diambil.

Sepengetahuan peneliti belum adanya penanganan gelandangan dan pengemis di Kabupaten Aceh Utara secara terpadu, berkesinabungan dan output yang dihasilkan, Seringkali gelandangan dan pengemis dimarjinalkan karena status mereka dalam masyarakat, hal inilah yang menggugah tim peneliti untuk mengakaji gelandangan dan pengemis secara konferehensif.

Berkaitan dengan penegakan hukum penanganan gelandangan dan pengemis juga mendapat penghukuman dilihat dari hukum pidana. R. Soepomo dalam Yesmil Anwar dan Adang memberikan definisi negara hukum ialah sebagai negara yang menjamin adanya tertib hukum dalam masyarakat artinya memberi perlindungan hukum pada masyarakat, dimana antara hukum dan kekuasaan ada hubungan timbal balik (Anwar, dkk, 2009: 121). Maka negara hukum merupakan negara yang mengemban kepercayaan dan perlindungan penduduk serta kemakmuran rakyat melalui kegiatan pembangunan bidang hukum diharap- 
kan kualitas hidup masyarakat Indonesia dapat ditingkatkan.

Kesejahteraan sosial terutama ditujukan untuk meningkatkan kebahagiaan atau kesejahteraan individu, kelompok, maupun masyarakat sebagai keseluruhan. Dapat pula mencakup upaya dan kegiatan-kegiatan yang secara langsung ditujukan untuk penyembuhan, pencegahan masalah sosial, misalnya masalah kemiskinan, penyakit dan disorganisasi sosial, serta pengembangan sumber-sumber manusia. Melihat konsepsi kesejahteraan sosial, ternyata masalah-masalah sosial dirasakan berat dan menganggu perkembangan masyarakat, sehingga diperlukan sistem pelayanan sosial yang lebih teratur. Dalam hal ini berarti bahwa tanggung jawab pemerintah semakin perlu ditingkatkan bagi kesejahteraan warga masyarakatnya. (Nurdin, 1990: 27-28)

\section{METODE PENELITIAN}

Berdasarkan latar belakang tersebut, maka yang menjadi pokok permasalahan dalam penelitian tentang "Kebijakan Penanggulangan Gelandangan dan Pengemis (Studi Penelitian Di Kabupaten Aceh Utara)" adalah Bagaimanakah kebijakan yang diambil oleh Pemerintah Kabupaten Utara dalam hal penanggulangan gelandangan dan pengemis? Ham- batan apa saja yang ditemui dalam penerapan kebijakan terhadap penanggulangan gelandangan dan pengemis di Kabupaten Aceh Utara?. Metode penelitian yang digunakan dalam penelitian ini adalah yuridis empiris bertipe sosiologi. Penelitian ini menggunakan fakta-fakta empiris yang diambil dari perilaku manusia, baik perilaku verbal yang didapat melalui wawancara maupun perilaku nyata yang dilakukan melakukan pengamatan langsung.

\section{HASIL DAN PEMBAHASAN}

\subsection{Gelandangan Gelandangan dan Pengemis Dalam Konsep Hak Asasi Manusia}

R. Soesilo mendefinisikan minta-minta atau mengemis dapat dilakukan dengan meminta secara lisan, tertulis atau memakai gerakgerik, termasuk juga dalam kategori pengertian ini adalah menjual lagu-lagu dengan jalan menyanyi main biola, gitar, angklung, seruling, musik serta menyodorkan permainan sepanjang toko-toko dan rumah-rumah yang biasa dilakukan dikota-kota besar. (Soesilo, 1988: 327)

Dengan demikian maka definisi pengemis adalah orangorang yang mendapat penghasilan dengan meminta-meminta ditempat umum dengan berbagai cara dan alasan untuk mengharapkan 
belas kasihan orang. Cara yang dimaksud adalah dengan mengamen atau melakukan minta sumbangan yang disertai dengan surat keterangan miskin yang dikeluarkan oleh Kepala Desa atau Camat yang memuat keterangan bahwa yang bersangkutan fakir miskin atau anak yatim.

\section{Entang Sastraatmadja} mengartikan gelandangan ialah sekelompok masyarakat yang terasing, mereka ini lebih sering dijumpai dalam keadaan yang tidak lazim, seperti dikolong jembatan, di sepanjang lorong-lorong sempit, di sekitar rel kereta api ataupun di setiap emperan toko, dan dalam hidupnya sendiri mereka akan terlihat sangat berbeda dengan manusia merdeka lainnya. (Sastraatmadja, 1987: 23)

Pendekatan humanistis dalam penanggulangan gelandangan dan pengemis sangat penting dikedepankan. Artinya bahwa pencegahan perbuatan mengelandang dan mengemis, tidak hanya pemberian pidana yang dikenakan kepada si pelanggar harus sesuai dengan nilai-nilai kemanusiaan yang beradab, tetapi juga harus dapat meningkatkan kesadaran si pelanggar akan nilainilai kemanusiaan dan nilai-nilai pergaulan hidup bermasyarakat. Apabila pidana akan digunakan sebagai sarana untuk mencapai tujuan tersebut, maka pendekatan humanistis harus pula diperhatikan, hal ini penting tidak hanya karena kejahatan itu pada hakikatnya merupakan masalah kemanusiaan, tetapi juga pada hakikatnya pidana itu sendiri mengandung unsur penderitaan yang dapat menyerang kepentingan atau nilai yang paling berharga kehidupan manusia. (Arief, 2010: 42)

Cesare Beccaria mengatakan bahwa kerasnya hukuman adalah tidak berguna, meski tidak seketika berlawanan dengan kebaikan publik atau menjadi akhir bagi maksud yang di emban, yaitu untuk mencegah kejahatan, kerasnya hukuman itu akan berlawanan dengan kebajikan dermawan, yang merupakan konsekuensi dari pemikiran pencerahan, yang menginstruksikan penguasa untuk berkehendak daripada sekedar memerintah manusia dalam keadaan bebas dan bahagia alih alih keadaan menjadi lebih baik. Kerasnya hukuman juga akan berlawanan dengan keadilan dan permufakatan sosial. (Beccaria, 2011: 7-8)

Keefektivan penerapan hukuman jelas tidak membawa manfaat maupun pendidikan bagi gelandangan dan pengemis, selama sistem peradilan pidana di Indonesia belum humanis. Persoalan humanis dalam hukum 
pidana sangat erat sekali dengan pendekatan humanistik, terlebih lagi bangsa Indonesia yang berdasarkan Pancasila dan garis pembangunannya bertujuan untuk membentuk manusia yang seutuhnya. (Yusrizal, 2011:24) Melihat pengaturan gelandangan dan pengemis dalam hukum pidana, maka penulis melihat adanya kesalahan dalam perumusan kebijakan legislatif yang menjadi kesalahan strategis dalam penegakan hukum. (Yusrizal, 2011: 24)

Bila kita merujuk pada ajaran Islam, apa yang dilakukan dalam penegakan hukum maka kita akan menemui berbagai kesalahan, bukankan islam mengajarkan ketauladanan dan keadilan tanpa pandang bulu, seperti yang disampaikan oleh Khalifah Umar bahwa seseorang pemimpin adalah orang yang disaatnya rakyatnya kelaparan maka ia adalah orang yang pertama kali merasakan lapar, dan disaat rakyatnya kenyang maka ia adalah orang yang terakhir yang merasakan kenyang, kita sebagai bangsa selalu mengabaikan nilainilai moral yang ada dalam agama. (Al-Fakih, 2006:10)

Solly Lubis mengatakan bahwa gagasan, cita-cita, atau idealisme penciptaan negara kesejahteraan, sangat erat hubungannya dengan perlindungan hak asasi manusia. Makin cenderung pemerintah mengemban hak asasi manusia maka makin dekat dengan misi dan visi pemerintah kearah negara kesejahteraan. Apalagi kalau tekad dan konsep perlindungan itu didalam Undangundang Dasar ataupun rencanarencana pembangunan, tidak sekedar dalam bentuk formal dan seyogianya harus berupa tindakan konkrit dan riil. (Lubis, $\mathrm{tt}$ )

Di Indonesia, kita masih berada pada tahap peletakan fondasi kostitusional mengenai perlindungan hak asasi manusia, dan masih jauh realisasinya sesuai dengan kepentingan-kepentingan masyarakat luas sebagai stakeholders. Namun demikian, dalam studi tentang service state and public service ini selayaknya diterapkan dalam Undang-Undang Dasar. Service State (negara pelayanan): yakni pelayanan demi kesejahteraan rakyat makin menonjol, dan semua potensi alami (natural resources) maupun pengerahan tenaga sumber daya manusia $(\mathrm{hu}-$ man resources) diarahkan kepada penciptaan kesejahteraan masyarakat lahir dan bathin.

Konsep hak asasi manusia bukan hanya tercantum dalam pernyataan hak asasi manusia sedunia atau deklarasi-deklarasi melainkan juga ia seringkali dituangkan dalam sejumlah konvensi, konstitusi, perundangundangan, teori serta hasil-hasil 
dari pemikiran. Tidak semuanya berjalan dengan baik, karena banyak diantaranya yang hanya merupakan sentuhan ironi dari untaian kata-kata indah dihadapan realitas kehidupan masyarakat. tak jarang bagian-bagiannya merupakan salinan literal yang sesungguhnya cuma cocok untuk realitas-realitas lain. (Kusumah, 1981:70)

Oleh sebab itu, kebijakan penaggulangan gelandangan dan pengemis perlu mendapat perhatian yang serius dari pemerintah. Hal ini dilakukan supaya gelandangan dan pengemis semakin dapat dikurangi bahkan dilhilangkan jika program pemerintah daerah mampu menjadi sentral dalam pencegahan dari kebiasaan tersebut.

\subsection{Pengertian Kebijakan Publik}

Kebijakan Publik (Public Policy) adalah suatu aturan yang mengatur kehidupan bersama yang harus ditaati dan berlaku mengikat seluruh warganya, setiap pelanggaran akan diberi sanksi sesuai dengan bobot pelanggaran yang dilakukan dan sanksi dijatuhkan didepan masyarakat oleh lembaga yang mempunyai tugas menjatuhkan sanksi.

James E. Anderson memberikan pengertian kebijakan sebagai serangkaian tindakan yang mempunyai tujuan tertentu yang diikuti dan dilaksanakan oleh seorang pelaku atau sekelompok pelaku guna memecahkan suatu masalah tertentu. (Anderson, 1984:12-13)

James E. Anderson secara lebih jelas menyatakan bahwa yang dimaksud kebijakan adalah kebijakan yang dikembangkan oleh badan-badan dan pejabatpejabat pemerintah. Pengertian ini menurutnya berimplikasi: (Anderson, 1984:12-13)

1. Kebijakan selalu mempunyai tujuan tertentu atau merupakan tindakan yang berorientasi pada tujuan;

2. Kebijakan itu berisi tindakantindakan atau pola-pola tindakan pejabat-pejabat pemerintah;

3. Kebijakan merupakan apa yang benar-benar dilakukan oleh pemerintah;

4. Kebijakan bisa bersifat positif dalam arti merupakan beberapa bentuk tindakan pemerintah mengenai suatu masalah tertentu atau bersifat negatif dalam arti merupakan keputusan pejabat pemerintah untuk tidak melakukan sesuatu, dan

5. Kebijakan, dalam arti positif, didasarkan pada peraturan perundang-undangan dan bersifat memaksa (otoritatif).

Pendapat ahli yang menyamakan kebijakan publik 
sebagai tindakantindakan pemerintah.Semua tindakan pemerintah dapat disebut sebagai kebijakan publik. Definisi ini dapat diklasifikasikan sebagai decision making dimana tindakan-tindakan pemerintah diartikan sebagai suatu kebijakan. Pendapat ahli yang memberikn perhatian khusus pada pelaksanaan kebijakan. Kategori ini terbagi dalam dua kubu, yakni : Mereka yang memandang kebijakan publik sebagai keputusan-keputusan pemerintah yang mempunyai tujuan dan maksud maksud tertentu dan mereka yang menganggap kebijakan publik sebagai memiliki akibat-akibat yang bisa diramalkan atau dengan kata lain kebijakan publik adalah serangkaian instruksi dari para pembuat keputusan kepada pelaksana kebijakan yang menjelaskan tujuan-tujuan dan cara-cara untuk mencapai tujuan tersebut. Definisi ini dapat diklasifikasikan sebagai decision making oleh pemerintah dan dapat juga diklasifikasikan sebagai interaksi negara dengan rakyatnya dalam mengatasi persoalan publik.

Kebijakan publik terdiri dari rangkaian keputusan dan tindakan. Kebijakan publik sebagai suatu hipotesis yang mengandung kondisi-kondisi awal dan akibatakibat yang bisa diramalkan (Presman dan Wildvsky). Definisi ini dapat diklasifikasikan sebagai decision making dimana terdapat wewenang pemerintah didalamnya untuk mengatasi suatu persoalan publik. Definisi ini juga dapat diklasifikasikan sebagai intervensi antara negara pada suatu masyarakat.

\subsection{Kebijakan Pemerintah Kabu- paten Utara Dalam Hal Pe- nanggulangan Gelandangan dan Pengemis}

Penjelasan Undang-Undang Republik Indonesia Nomor 12 Tahun 1995 tentang Pemasyaratan adalah Bagi negara Indonesia yang berdasarkan Pancasila, pemikiranpemikiran baru mengenai fungsi pemidanaan yang tidak lagi sekedar penjeraan tetapi juga merupakan suatu usaha rehabilitasi dan reintegrasi sosial Warga Binaan Pemasyarakatan telah melahirkan suatu sistem pembinaan yang sejak lebih dari tiga puluh tahun yang lalu dikenal dan dinamakan sistem pemasyarakatan. Walaupun telah diadakan berbagai perbaikan mengenai tatanan (stelsel) pemidanaan seperti pranata pidana bersyarat (Pasal 14a KUHP), pelepasan bersyarat (Pasal 15 KUHP), dan pranata khusus penuntutan serta penghukuman terhadap anak (Pasal 45, 46, dan 47 KUHP), namun pada dasarnya sifat pemidanaan masih 
bertolak dari asas dan sistem pemenjaraan, sistem pemenjaraan sangat menekankan pada unsur balas dendam dan penjeraan, sehingga institusi yang dipergunakan sebagai tempat pembinaan adalah rumah penjara bagi Narapidana dan rumah pendidikan negara bagi anak yang bersalah.

Isu Penyandang Masalah Kesejahteraan Sosial (PMKS), diantaranya gelandangan dan pengemis merupakan fenomena yang dikaji secara sosial tidak bisa dihindari dari ketidakberdayaan secara ekonomi serta tekah membudanya aktivitas tersebut secara psikologis. Jika melihat secara lebih mendalam, maka pemerintah sebagai regulator dan eksekutor harus memaksimalkan perannya dalam pencegahan dan penanggulangan gelandangan dan pengemis.

Melihat sketsa munculnya pengemis, dapat dipahami bahwa ada juga perbuatan pengemisan itu dilakukan secara teroganisir. Hal ini terlihat dari adanya pembagian wilayah kerja, pemanfaatan anakanak, dan adanya pembagian waktu kerja yang jelas. Oleh sebab itu, peranan Pemerintah Kabupaten Aceh Utara sangat penting untuk dilakukan supaya permasalahan sosial seperti ini dapat diselesaikan.

Dinas sosial, Pemberdayaan Perempuan dan Perlindungan
Anak Kabupaten Aceh Utara adalah satuan kerja perangkat daerah yang melaksanakan kegiatan pada bidang kesejahteraan masyarakat dan sosial. Perangkat daerah ini mempunyai peran dan tugas melaksanakan urusan pemerintahan di bidang sosial, diantaranya adalah Penyandang Masalah Kesejahteraan Sosial (PMKS).

Penyandang Masalah

Kesejahteraan Sosial (PMKS) adalah perseorangan, keluarga, kelompok atau masyarakat yang karena suatu hambatan, kesulitan, atau gangguan, tidak dapat melaksanakan fungsi sosialnya, sehingga tidak dapat terpenuhi kebutuhan hidupnya baik jasmanai, rohani, maupun sosial secara memadai dan wajar.

Keseriusan dan kecakapan

Dinas sosial, Pemberdayaan Perempuan dan Perlindungan Anak Kabupaten Aceh Utara dalam penanggulangan pengemis adalah sebuah tugas pokok struktur organisasi yang berkaitan dengan masalah sosial baik gelandangan, pengemis dan masalah sosial lainnya. Dimana dalam penanganannya perlu bekerja sama dengan Satpol Pamong Praja untuk merazia gelandangan dan pengemis.

Salah satu upaya memutus mata rantai yang terus berkelindan 
gelandangan dan pengemis adalah tersedianya rumah singgah atau panti sosial lengkap dengan sarana dan prasarana untuk dilakukannya pembinaan selama didalam rumah singgah. Keseriusan dan tekad untuk berubah bagi peserta dalam rumah singgah membuat arus gelandangan dan pengemis semakin dapat ditekan secara perlahan. Penyebab ketiadaanya rumah singgah adalah karena dukungan pendanaan belum berpihak terhadap Penyandang Masalah Kesejahteraan Sosial (PMKS).

Persoalan terkait gelandangan dan pengemis, Dinas sosial, Pemberdayaan Perempuan dan Perlindungan Anak Kabupaten Aceh Utara melalui Sekretaris Dinas sosial, Pemberdayaan Perempuan dan Perlindungan Anak Kabupaten Aceh Utara oleh Bapak Syarifuddin, S.T, menyebutkan ada beberapa kebijakan yang telah dilakukan, walaupun dalam kebijakan atau upaya yang telah dilakukan belum meksimal, setidaknya Pemerintah daerah Aceh Utara telah berbuat. Beberapa kebijakan diantaranya adalah:

$\begin{array}{lr}\text { 1) Pemerintah } & \text { Kabupaten } \\ \text { Aceh Utara } & \text { melalui Dinas } \\ \text { sosial, } & \text { Pemberdayaan } \\ \text { Perempuan } & \text { dan } \\ \text { Perlindungan } & \text { Anak } \\ \text { Kabupaten Aceh Utara dan }\end{array}$

Satuan Polisi Pamong Praja melakukan penertiban/razia terhadap gelandangan dan pengemis.

2) Dilakukannya pemberdayaan Pengemis, seperti diberikan pelatihan keahlian sesuai minat dan bakat, juga adanya pemberdayaan ekonomi yang bersifat produktif yang anggarannya berasal dari APBK dan APBA.

3) Diberikannya bantuan langsung tunai untuk menopang perekonomian yang termasuk penyandang masalah kesejahteraan sosial;

4) Menariknya, para pengemis yang cacat secara fisik menjai tukang pijat yang kegiatan ini mampu menopang perekonomian secara finansial.

Banyak kegiatan yang dilakukan, namun selesai pelatihan keahlian mereka kembali mengemis. hal ini dipicu oleh perbuatan mengemis lebih menguntungkan dan tidak perlu kerja keras. Di Kabupaten Aceh Utara keberadaan gelandangan dan pengemis merupakan suatu fenomena yang biasa terlihat. Penyebab utamanya pemerintah Kabupaten Aceh Utara belum melihat persoalan gelandangan 
dan pengemis sebagai persoalan yang serius apabila tidak ditangani secara dini.

Di pihak yang lain,
adakalanya gelandangan dan
pengemis tidak bisa dipersalahkan
secara secara menyeluruh. Hal ini
disebabkan pemerintah belum
melakukan suatu terobosan dan
grand design terkait pencegahan
dan penanggulan gelandangan den
pengemis tersebut. Visi dan misi
pemerintah Kabupaten belum
menyentuh secara substansial
perihal gelandangan dan
pengemis.
pengemis.

Menurut Fukuyama, bahwa negara harus diperkuat, kesejahteraan tidak mungkin dicapai tanpa hadirnya negara yang kuat, yang mampu menjalankan perannya secara efektif. Begitu pula sebaliknya, negara yang kuat tidak akan bertahan lama jika tidak mampu menciptakan kesejahteraan rakyatnya. (Fukuyama, 2005:87)

Perlu kesungguhan semua pihak. Implementasi lapangan yang maksimal guna menunjang tersoaialisasi dan penerapan tentang perlpenertiban gelandangan dan pemgemis. Cara mengatasi permasalahan tersebut yaitu dengan penyuluhan dan konseling, pendidikan pelatihan keterampilan, pengawasan serta pembinaan lanjut, penertiban oleh aparat pemerintah, penampungan di panti sosial dan panti jompo, rehabilitasi, pembangunan perumahan sangat sederhana, pengadaan rumah singgah dan diberikan pelatihan dan pendidikan, dan transmigrasi. Kebijakan-kebijakan pemerintah yang telah disebutkan di atas tentunya tidak akan berarti apabila pemerintah tidak mewujudkannya secara konsisten dan konprehensif untuk penanggulangan kemiskinan di Kabupaten Aceh Utara.

\subsection{Hambatan Dalam Penanggulangan Ge- landangan dan Pengemis Di Kabupaten Aceh Utara}

Salah satu fungsi dari keberadaan Dinas sosial, Pemberdayaan Perempuan dan Perlindungan Anak Kabupaten Aceh Utara adalah mencakup kegiatan mensejahterakan masyarakat. Ada beberapa upaya yang sudah dilakukan penanggulangan gelandangan dan pengemis di Kabupaten Aceh Utara, yakni melakukan razia terhadap gelandangan dan pengemis dan selanjutnya memulangkan mereka ke tempat asalnya. Tindakan razia ini tidak memberikan efek jera dan terksesan menganggap sepele. Hal ini ditandai banyaknya pengemis yang terjaring razia setelah dipulangkan, tidak lama 
kemudian beroperasi kembali dengan jumlah yang lebih banyak lagi. Lemahnya penegakan hukum juga menjadi salah satu penghambat dalam hal penanggulangannya.

Sebagaimana uraian diatas, ada beberapa faktor yang menjadi hambatan bagi Dinas sosial, Pemberdayaan Perempuan dan Perlindungan Anak Kabupaten Aceh Utara dalam menanggulangi permasalahan pengemis sebagaimana di jelaskan oleh Said Syahrial, S.H., Pelaksana Harian Kepala Bidang Rebilitasi, antara lain:

1. Persoalan mentalitas dari gelandangan dan pengemis.

2. Belum adanya rumah singgah bagi gelandangan dan pengemis di Kabupaten Aceh Utara.

3. Peranan stakeholder belum maksimal dalam melakukan penanganan secara konferehensif terkait gelandangan dan pengemis.

4. Belum adanya intervensi pembangunan khususnya pembangunan sumber daya manusia untuk peningkatan kapasitas gelandangan dan pengemis.

5. Anggaran yang tersedia masih sangat kurang, sehingga menghambat program pembinaan bagi pengemis.
6. Belum maksimalnya koordinasi antar perangkat daerah, hal ini perlu ditindaklajuti secara serius dalam bentuk nota kesepakatan bersama.

7. Masih banyak masyarakat yang tidak mengindahkan himbauan larangan memberikan sedekah kepada pengemis. Sehingga membuat semakin menjamurnya para pengemis di Kabupaten Aceh Utara.

Penanganan masalah gelandangan dan pengemis ini tidak terlepas dari penanganan kemiskinan itu sendiri, terutama jika dilihat dari sudut pandang daerah asal gelandangan dan pengemis. Memang, kemiskinan bukanlah satu-satunya penyebab terjadinya kegiatan menggelandangan dan mengemis tetapi bisa juga menjadi akar penyebab. Maka hambatan yang terbesar dalam penanganan gelandangan dan pengemis adalah mentalitas.

\section{KESIMPULAN}

Ada beberapa kebijakan yang telah dilakukan oleh Pemerintah Kabupaten Aceh Utara melalui Dinas sosial, Pemberdayaan Perempuan dan Perlindungan Anak Kabupaten Aceh Utara dan Satuan Polisi Pamong Praja melakukan 
penertiban/razia terhadap gelandangan dan pengemis, Dilakukannya pemberdayaan Pengemis, seperti diberikan pelatihan keahlian sesuai minat dan bakat, juga adanya pemberdayaan ekonomi yang bersifat produktif yang anggarannya berasal dari APBK dan APBA. Walaupun dengan anggaran sangat minimal.

Ada beberapa hambatan dalam penanganan gelandangan dan pengemis di Kabupaten Aceh Utara diantaranya: faktor mental, Belum adanya rumah singgah bagi gelandangan dan pengemis di Kabupaten Aceh Utara, Peranan stakeholder belum maksimal untuk secara bersama menangani dan menaggulangi gelandangan dan pengemis, Belum adanya intervensi pembangunan khususnya pembangunan sumber daya manusia untuk peningkatan kapasitas gelandangan dan pengemis, anggaran yang disediakan oleh pemerintah Kabupaten Aceh Utara sangat minim, belum maksimalnya koordinasi antar perangkat daerah di Kabupaten Aceh Utara.

\section{DAFTAR PUSTAKA}

Al-Faqih, M.Z. 2006. "Negara Ideal St. Ausgustine: Adakah Negara Indonesia Itu". Jurnal Governance, Pusat Penelitian Kebijakan dan
Pengembangan Wilayah Lembaga Penelitian Universitas Padjadjaran, vol. 2 No. 8.

Anderson, J. E. 1984. Public Policy Making, New York: Holt, Rinehart and Winston.

Anwar, Y. dan Adang. 2009. Sistem Peradilan Pidana (Konsep, Komponen, dan Pelaksanaannya Dalam Penegakan Hukum Di Indonesia), Bandung: Widya Padjadjaran.

Arief, B. N. 2010. Kebijakan Legislatif Dalam Penaggulangan Kejahatan Dengan Pidana Penjara, Yogyakarta: Genta Publishing, 2010

Beccaria, C. 2011. Perihal Kejahatan dan Hukuman, Yogyakarta: Genta Publishing.

Fadhil, N. M. 1990. Pengantar Studi Kesejahteraan Sosial, Bandung: Angkasa.

Fajar, N. D. Mukti dan Yulianto, A. 2010. Dualisme Penelitian Hukum Normatif dan Empiris, Yogyakarta: Pustaka Pelajar.

Fukuyama, F. 2005. State-Building: Governance and World Order in the 21st Century (Memperkuat Negara: Tata Pemerintahan dan Tata Dunia Abad 21), Jakarta: Gramedia.

Kusumah, M. W. 1981. Hukum dan Hak Asasi Manusia Suatu Pemahaman Kritis, Bandung: Alumni.

Lubis, M. S. tt. Teori Hukum, Politik Hukum, Kebijakan Publik, Hukum 
dan Kebijakan Publik, Medan: Sekolah Pascasarjana Universitas Sumatera Utara.

Sastraatmadja, E. 1987. Dampak Sosial Pembangunan, Bandung: Angkasa.

Soekanto, S. 1986. Pengantar Penelitian Hukum, Jakarta: UI Press.

Soesilo, R. 1988. Kitab UndangUndang Hukum Pidana Serta Komentar-Komentarnya Lengkap Pasal Demi Pasal, Bandung: Karya Nusantara.

Yusrizal, 2011. "Dekriminalisasi Terhadap Gelandangan dan Pengemis Dalam Perspektif Politik Hukum Pidana". Yustitia, Jurnal Hukum Universitas Muhammadiyah Surabaya, Vol. 5 No. 1 April. 